\title{
DISCUSSING THE SUPERNATURAL IN CONTEMPORARY FINLAND: DISCOURSES, GENRES, AND FORUMS
}

\author{
Kaarina Koski
}

\begin{abstract}
The supernatural is a debated issue on the Internet even though people generally avoid face-to-face discussion about it. This article ${ }^{1}$ gives an analytical overview of discussions about the supernatural in contemporary Finland. The research material consists of a sample of Finnish media and online discussions about the supernatural, as well as letters describing and interpreting personal experiences. Texts published on different forums show different generic features of style, content, and the traditionality of expression and interpretations. The texts can be entertaining or argue about moral and ontological issues, about the emergence of these experiences in human mind, or the status and sanity of people who have had these experiences. Opinions and interpretations on all forums draw on various discourses, of which five are presented. The science-oriented and mental discourses seek for natural explanations. The spiritual reality is accounted for, albeit in different forms, in the popular Christian, fundamental Christian, and alternative spiritual discourses. The discourses can be combined in various ways. The experiencers themselves primarily seek legitimate interpretations and sometimes they modify or stretch the collectively accepted scientific or Christian worldview to fit their experiences. However, sometimes the experiences lead to a change of the worldview. The sciences are also criticised for their narrow attitude.
\end{abstract}

Keywords: Christian, discourse, experience, interpretation, legitimacy, mental, scientific, spiritual, supernatural

\section{INTRODUCTION}

It is difficult to interpret or explain experiences that seem to be beyond our understanding of the ontology of everyday reality. Various belief systems interpret such experiences as supernatural, divine, or paranormal. Institutionalised religions are selective about what kinds of experiences they find appropriate. Scientific worldview, in turn, denies the existence of such phenomena altogether and suggests that the experiences originate in the person's own mind.

Scholars of religion characterise Nordic societies as post-secular: the public sphere is secular and relies on natural sciences but various religious activities 
have visible roles in public and political life, making the society pluralistic (Casanova 2012: 30-32). At the beginning of the 20th century, 98\% of the Finnish population were still members of the Lutheran Church. In the year 2014, the percentage was $73.7 \%$ while the amount of the non-religious had grown (Ev.lut.kirkko 2014; Palmu et al. 2012: 29). At the same time, there are over 600 different religious or alternative spiritual societies in Finland (Ketola 2007: 33 , and the contradiction felt between religion and science is milder than in most European countries. There are no substantial differences between the values held by religious and non-religious population. One reason is that the Lutheran Church has affected the moral atmosphere of Finland for centuries (Ketola \& Kääriäinen \& Niemelä 2007). In this context, namely non-Christian supernatural or paranormal experiences and beliefs are regarded as inappropriate and illegitimate for both religious and scientific reasons. Especially the science-oriented sceptics who represent the core values of the society actively defend their superior worldview against what they regard as gullibility, ignorance, stupidity, and the corruption of reason.

Yet, there are still people who do report having had experiences that they regard as supernatural. They may see grey or bright figures that they interpret as dead relatives, spirits, extraterrestrials, or angels. They may hear voices that give advice and save them from danger or scold and humiliate them. They can feel a hand on their shoulder, or a cold or fragrant whiff in the air (see, e.g., Laiho \& Kaunonen \& Aho 2014: 51). Especially when the sensation is very strong or the experiences occur frequently, people urge to find an interpretation and explanation to the phenomenon. Even though researchers have found a strong correlation between paranormal beliefs and extraordinary experiences (e.g. Pechey \& Halligan 2012), the latter occur also among those who have no such beliefs (Woodard 2012). Especially for people with a secular worldview, finding a meaningful and reasonable explanation is a challenge and may require changing one's worldview and rejecting the publicly legitimate expectations.

People whose experiences differ from their own expectations as well as from the legitimate mainstream views adopt various strategies in their search for meaningful explanations and legitimacy. The three major frames of reference to interpret one's unusual experiences in Finland, as well as generally in the Western world, are: the scientific, the Christian, and the alternative spiritual (see Gilhus 2012: 240; Northcote 2007: 53). The institutional legitimacy of science and Christianity makes people want to rely on them even if their experiences do not actually fit into the frame. If the difference between the experience and the legitimate meaning system is unbridgeable, people turn to alternative spiritual interpretations. However, not everybody considers it necessary to find a special explanation. In some families precognition and omens have been fre- 
quent enough to make these phenomena seem almost ordinary and natural to the family members. Furthermore, some people simply accept that inexplicable things happen and do not find it disquieting.

In this article, I analyse the collision between the experiences that have no legitimate interpretative frame and the unwelcoming public discussion. I study the ways people make sense of their experiences and the power struggles that permeate the discussions and interpretations, and use discourse analysis and genre approach to structure the discussions, narratives, views, and attitudes around the supernatural and unusual experiences.

\section{INTERNET FORUMS, NARRATIVES, AND GENRES}

My research material consists of various written sources that touch upon the topic of the extraordinary or supernatural experiences. A greater part of my research material originates from the Internet, which has become an important forum for discussing the supernatural and extraordinary experiences. People who are afraid of losing their face if they reveal their controversial experiences to others can share their thoughts and questions anonymously on the Internet. In many cases, the Internet also appears to be the most preferred channel to find information about these things (see, e.g., Hiiemäe forthcoming). I have used professional media content, such as articles and blogs from newspapers and magazines, to outline the public discussion about these topics. To study the popular response and opinions, I have used internet comments to the media content as well as posts on various discussion forums. I have also used a collection of letters that were sent to the research project Mind and the Other during the years 2013-2014. The internet materials create a cultural context for the experiences and feelings reported in the letters, which, in turn, deepen the view of the experiences and interpretations.

The internet discussions that I have analysed can be divided roughly into three types, which show slightly different attitudes and styles. The first type is internet forums and comment threads of daily news with a wide reception. These forums are known for their thoughtless and rude comments, so it is not surprising that here the reluctant and stigmatising attitude towards the topic is most salient. Below is a typical reaction to an article of seers:

What kinds of drugs do these shamans take? I have also been pissed sometimes, but I have never seen gnomes. People used to be taken for treatment when they saw little men! (IS_Vir/Lapponia 22.1.2014, 19:42) 
Generally, the comment threads of daily news do not focus on the ontological questions per se but show the weak status of deviant experiences and beliefs in a society that they, according to the dominant attitude, do not and should not belong to. The focus is on the people involved in esoteric activities and on what is wrong with them: either mental health or morals. I will return to the features of public discussion further on.

The second type is discussions or sites particularly dedicated to extraordinary experiences or the supernatural. On these specialised forums, the discussants have more information about the topic than on the general sites (see also Hiiemäe forthcoming). They are also more committed to the subject and find it worth discussing. Not only the experients but also their opponents generally make a more justified and careful contribution. These forums often include detailed descriptions of experiences and personal interpretations about the connections to another reality:

I am not afraid of death. My mother and my child left for the hereafter and they have both sent me messages. We go home when we die. Only now I am sure about it, because after my child's death I did not believe in anything anymore, I was just angry and bitter - time helped me to understand my child's messages. Be open, ask angels to help you, pray! And you will be shown. I don't even belong to church myself, religions have been invented by us on earth, but we all have a common god, which is love itself. Our dead loved ones constantly visit us. And we all have the ability to sense them if we just close our minds for a moment to all this surrounding fuss, trivialities, and reasoning, and trust our intuition. Full stop. (S24_KEF/ en pelkää 29.7.2011, 01:35)

The third type consists of sites in which people are invited to send ghost stories. I have focused on one ghost story site that was established by a daily newspaper in 2010. The invitation read: "Share your own ghost story with the readers! It can be a so-called true story, your own experience that seemed supernatural - or just a story that has given you the creeps" (IS_Kumm). The site received 230 posts, which included both traditional and first-hand experience narratives, comments to them, discussion about interpretations, and also encouraging comments from the audience, such as: "I have never encountered a ghost, but I love ghost stories. I hope this thread will be looooong!" (IS_Kumm/Essi 16.2.2010, 19:56)

Narratives on this forum show similarity with older legend tradition at least in three respects. First, unlike in the other internet discussions and the letter material, there are expressions of collective moral and belief tradition, such as the moral point that the deceased comes to express his/her disapproval if the offspring ignores his/her wishes. Second, the stories are aesthetically elabo- 
rated: they have a neat and self-validating narrative structure that makes them dramatic and entertaining. A typical storyline first describes the setting and the haunting event. Later the protagonist is told that the haunting had been earlier sensed by others as well, and that a tragedy - an accident, murder, or some other premature death - has happened in that place:

I was visiting a summer cottage of an acquaintance. He asked me to heat the sauna. Well I went and filled the water cauldron and put wood into the stove. I felt like smoking a cigarette on the steps. It was a calm afternoon. While I was smoking I felt a very cold current of air passing me. I wondered what it was.

Well I talked about it in the house. The owner said it was nothing new, he had heard the floor creaking when he stayed overnight in the house, even though there was no one else.

Afterwards, I heard that a person had been murdered in that house. (IS_Kumm/Jarski 16.2.2010, 17:55)

A third feature in which this corpus parallels with the older legend tradition and its collectivity is that in these stories haunting is often connected to places. In the letter material as well as on discussion forums, the experiences and abilities are personal and almost entirely related to the experiencing individual. A place, in turn, gets a reputation as being haunted when there are multiple collectively shared encounters. This also shifts the responsibility for seeing weird things away from the narrator: it is not him or her that keeps seeing things but it is the place in which anyone could have experienced it.

In belief narrative tradition, the wish to discuss one's own experiences and the limits of reality is combined with the desire for entertainment. In a later stage of the thread, the discussion develops in two directions: arguments over whether the experiences need to be scientifically explained or not, and popular horror movies and novels. On ghost story forums, the questions about ontology or appropriateness are not salient. Instead, the stories are legitimate as entertainment - the creepier the better.

In addition to internet sources, I have a collection of nearly 200 letters that people have spontaneously sent to researchers. These letters have been carefully anonymised and the names given to the writers are aliases. This collection (MT) started when the research project Mind and the Other, financed by the Finnish Academy's Human Mind programme, started its work in 2013 and received some publicity in the traditional media. Dozens of people who are involved in these issues contacted us to share their experiences, to bring forth their suppressed truth and also to offer their contribution to the research. The letter corpus is valuable but the researchers also realise it is biased in two re- 
spects. First, the age distribution of the writers concentrates on middle-aged and older. The younger generations are absent - perhaps because they have discussed their experiences on the Internet. Second, it is known that spiritual or New Age circles appreciate personal experiences and are generally critical about the sciences (Partridge 2005: 75-76). These people who spontaneously chose to share their experiences with an academic research group appear more sympathetic to sciences than spiritually inclined people in general. In addition to describing their experiences, the writers have expressed their gratitude to researchers for studying these issues, offered their help, given tips to the researchers and wished luck to the project. While this has been encouraging, in research it forms a bias. These biases I have hoped to repair with internet materials. People who wrote to us trusted that the researchers who read the letters would understand and respect them. Nevertheless, many of them first emphasised that they were healthy and normal. They wished that the researchers would finally illuminate the problem of their out of the ordinary experiences, such as the following:

This happened in the 1980s. In the small hours, I dreamed that my father had a big wound in his head and was bleeding terribly. The dream was so distressing that I had to call my mother and ask her if everything was OK. I started by asking whether my dad was all right, to which my mother answered, how come you know about it already; we just came back from the hospital. My father had had a cerebral infarction and been taken to hospital. (Helena MT 12/2)

The style of the letters is intimate and the meanings they convey are personal. The circumstances of the experiences, as well as the social relations with people involved, are carefully explained. Many writers present scientific, Christian, or spiritual frames of reference to explain or analyse what happened, but practically no one applies any moral or other narratively motivated solution to the encounter. Compared to the ghost stories above, which resemble traditional belief legends, these letters could be characterised as personal experience narratives that also used to be called memorates. ${ }^{2}$ The narrator is truly committed to the narrated event and the story or description has maximum personal relevance and no aspiration towards traditional meanings or entertaining performance. Furthermore, while the motifs and contents of the ghost stories mainly iterate collectively known imagery likely to be accepted by the audience, the descriptions in the letters are not standardised. For example, farewells from the deceased loved ones are common in both materials, but only the letters involve farewells also from dogs and cats. A personal relationship with a pet is very important to many people today, but visits from deceased pets are a relatively 
new phenomenon and not - at least not yet - recognised in collective belief tradition.

Many of the writers at least implicitly maintain that there is something very general or even universal in their experiences. In this respect, the experience narratives have a testimonial character. Testimonies are reactions to situations where there are competing truths. The concept has been used in connection to politically suppressed people's life experiences. Anthropologist and oral historian Vieda Skultans (1997) introduced the term to describe Latvians' narratives about their fates in the Soviet period. In this sense, the testimonial aspiration is wider than in traditional storytelling, in which the narrator wants to prove that the narrated event has truly taken place. Here, testimonies of supernatural encounters stand for all the people whose uncanny experiences have been neglected or stigmatised by the majority, by the church, medicine, and science. They testify to the suppression and disapproval they have faced:

I have had a deep feeling of being different and not understood. I have been judged because of my spirituality and because I see and experience more than others. Today I hide this side of me from all but those adept in these issues. If I want to manage in working life well enough to earn a normal income, I cannot risk being labelled as a nutcase. (Laura MT 71/1)

By sharing their stories, the writers want to make the world understand and acknowledge their reality. Almost all the letters are from people who have experienced something uncanny or supernatural themselves. Opposing views and discourses are, nevertheless, present in their texts as they constantly defend themselves against the critique inherent in the dominant worldview.

Some of the letters are from individuals who have, after active seeking, found or developed a spiritual worldview, either a personal one or within a society of the like-minded. A few of these writers also function as psychics or channel spiritual energies and messages. These specialist practices, as well as the wide field of spiritual and esoteric societies and entrepreneurs in Finland, are beyond the scope of this study.

\section{THE PARANORMAL TURN}

Since the 1970s, researchers have observed a growing interest in the occult and paranormal in the Western world. Supernatural motifs and esotericism have been estimated to have entered the Western mainstream culture, and not exclusively as fiction (Northcote 2007: 170-172; Partridge 2013: 115-117). On the one hand, supernatural topics and motifs have permeated popular culture and 
the media. On the other hand, alternative spiritual beliefs and practices such as Neo-Paganism, eastern meditative practices, and esoteric traditions have gained popularity in the religious life, while institutional religions are declining. Christopher Partridge has named the commonly shared reserve of esoteric ideas and the various ways to use it occulture. He portrays occulture as part of ordinary life in the Western world (Partridge 2013). While this development is without doubt in motion, we should remember there is also an opposition to it. The rise of paranormal interests has been followed by the emergence of sceptical societies as well (Northcote 2007). Furthermore, not all the developments reported in the Western countries have occurred in the same form in Finland.

The metamorphosis of religious life has been characterised as a spiritual revolution, which goes hand in hand with the need for more democratic religious societies and personal experiences. Younger generations prefer self-centred spirituality in which one's own experiences are the final authority, to the collective and hierarchical religious institutions in which one has to conform to an external, higher authority. At the same time, they turn from adherents to clients and choose elements for their spiritual life from various sources. This tendency is part of a subjective turn in the Western world (Heelas \& Woodhead 2005: 2-5; Ketola 2007: 30; Lassander 2014: 15). The theory of spiritual revolution, however, needs some modification when applied to Finland. First of all, religiosity and spirituality are not mutually exclusive: Finnish survey data show that a third of the population identifies themselves as both religious and spiritual. Furthermore, not only the spiritual activities have grown but also the independent Neo-Charismatic denominations, especially Pentecostalism, have increased in popularity (Ketola 2007). In other words, the structural change of religiosity leads to a shift from institutional forms to small, more democratic groups, but does not always involve the adoption of new spiritual imageries.

In the field of popular culture, the so-called paranormal turn has brought occult and supernatural motifs into the core of popular fiction and television shows. In many countries it has also introduced a variety of commercial products, such as psychic magazines, legend tripping tours, and ghost hunter kits. Annette Hill suggests that one reason for this tendency is the participating audience that seeks for uncanny experiences. The commercial production follows this demand (Hill 2011: 1-8). The film industry has partly superseded the old narrative traditions and, indeed, many popular films reiterate and update traditional folklore motifs (Schechter 2001 [1988]). It has been noted that even openly fictional contents have an impact on the readers' and viewers' thinking and increase their belief in the supernatural (see Bao about supernatural thrillers in this volume). Therefore, fictive films and texts cannot be considered as mere entertainment (Dégh 2001: 248-251; Goode 2000: 196). 
As serious face-to-face discussion on these topics is scarce, horror movies are sometimes the main source of information about certain supernatural beings. Occasionally, interpretations of strange experiences are taken from movies (see Hiiemäe forthcoming).

Erich Goode has argued that the media is sympathetic to the paranormal because it provides astonishing news. The tabloids publish items that could be characterised as folklore and affirm the paranormal claims. In empirical research, it has been found that uncritical media content increases the recipients' beliefs in the paranormal, whereas critique presented by authorities diminishes them. The stance of the tabloids is based on the fact that paranormal claims sell better than scientific facts. In the United States and Great Britain, occult and paranormal news are recurrent in tabloids with a low prestige. Prestigious newspapers, in turn, keep to scientific scepticism which is, after all, the dominant view in Western societies (Goode 2000: 193-196; 202-204). If we compare the media in the United States and Great Britain to Finnish media, we can detect considerable differences. The afternoon newspapers sold in Finland are not similar to the yellow press that advertises with sensational headlines. While it is true that the supernatural has gained access to the mainstream media during the past few years, it would be an exaggeration to regard the Finnish media particularly sympathetic to it. In the following, I aim to show how the public reacts to supernatural experiences and articles on paranormal topics.

\section{PUBLIC DISCUSSION AND CONTROL}

Public discussion ${ }^{3}$ consists of the expressions, opinions, and values that are publicly uttered in the media with a wide reception. As concerns supernatural issues, the same views and attitudes dominate the factual content of national broadcasting and the press, as well as internet discussions that have a wide public visibility. The voice of experts and professionals, such as researchers, politicians, officials, and journalists is well presented. However, the Internet has given the floor to the audience as well. Public discussion is not a static and univocal formation. It is spiced with expressions, texts, and arguments that challenge or confront the default expectations. Both professionals and laymen, however, practice control by opposing deviant views and strengthening the mainstream discourses. Deviant views can be publicly invalidated or they can end up in the margins ignored, disapproved, or not taken as serious arguments. The depreciation in public does not prevent these issues from being discussed and favoured on special forums, in micro-public spheres that focus on topics beyond the mainstream. The marginality of these forums diminishes the public interest and control (Northcote 2007: 2-3). 
Despite the increased visibility in Finnish media, supernatural and paranormal issues are marginal in public discussion. Disapproval, repression, and censure are on offer if such topics try to penetrate the factual core of the society. Public discussion in Finland has not been particularly welcoming, and readers do not expect prestigious newspapers to touch upon these issues. In the mainstream media, positive or neutral stance towards the supernatural can most probably be found in periodicals that are not profiled as serious reading 4 and include such topics in touching stories as entertainment. While there is interested audience for such articles, a controversial topic also triggers negative and resentful comments. When a women's magazine published an article about a married couple who practised unicorn healing, there were numerous critical comments:

I don't know which I am more upset about: that such shocking phony is on offer or that [the magazine] writes an article about it. For my part, I thus totally condemn your publication. This was too much. (MNYks/ Visitor 25.1.2015, 18:18)

I thought [the magazine] was of quality in its genre. To write a seemingly neutral story about such 'healers' is irresponsible and underrates the readers. (MNYks/Visitor 26.1.2015, 6:52)

The response was even more negative when a popular channel of the state broadcasting company YLE published a short news article about the same undertaking. In this case, the inexperienced reporter had apparently found the topic funny and unbelievable and, perhaps to make the joke more efficient, also included the information of how to attend a course to become a unicorn healer. The article raised strong reactions and was later judged by the Public Council of Mass Media for surreptitious advertising and a lack of source criticism (Yleisradio 2015). However, many readers shared the interpretation that the news was nothing else than humour. It was possible to view the release in the context of the contemporary vernacular practice to share on the Internet ironically unbelievable topics that nobody would take seriously. While the majority of comments expressed disapproval towards the fact that a state-driven company promoted such humbug and judged the article as "unsuitable to norms and values" (YleX/kekekeee 29.1. 2015, 21:25), the more entertained readers argued it was humour or continued the joke:

Nobody is stupid enough to take this news or the education seriously... (YleX/Valon voima 27.1.2015, 05:57) 
This must be pure humour. (YleX/Elmeri 29.1.2015, 10:10)

Long live sarcasm! A concept unknown to so many? (YleX/mipu 17.2.2015, 13:24)

If you meet a unicorn, please do not take more bleach. (YleX/Kuukupööpötin 27.1.2015, 18:01)

There were only a couple of comments that slightly defended alternative healing in general, and there was no dispute about the suitability of making jokes about unconventional beliefs. Besides the fact that many commentators declared the article as 'shit', the problem seemed to be that the news forum was no place for jokes and the text was thus judged as factual. As the above example shows, the public discussion is controlled both by the audience and by professionals. A journalist can also be reproached by colleagues. ${ }^{5}$

The society actively defends its core values against violations. It is witnessed in many societies that those in power suppress the morally, culturally, or racially other, who they perceive as a threat or challenge to the prevailing order and values. The other is stigmatised, which means that the whole person is judged by the one deviant feature and deprived of his or her value as a community member (Dijker \& Koomen 2007: 6-7). The fear of being stigmatised makes the majority of people with supernatural experiences keep silent about them. Especially on discussion forums and sites with a wide publicity, there are rude comments towards the deviant, and also a clear aspiration to suppress a serious discussion about the topic:

Insanity and ignorance keep increasing (at least if we believe in these discussion forums). People who see gnomes should be taken to compulsory hospitalisation. (IS_Vir/qwerty 22.01.2014, 20:48)

Seeing angels and such things is a sign of unstable mental health. There is nothing else to discuss. Full stop. (IS_Vir/JRe 23.01.2014, 09:46)

Sociologist Jeremy Northcote uses the term paranormal debate for all the disputes and discussions on various forums in the Western society, which concern the ontology, epistemology, and ideology of the paranormal or supernatural. He has noted that the main hindrance for reaching or even approaching any consensus about ontological questions is the attitude of the participants. $\mathrm{He}$ writes that opponents are seen as demonic other, who threaten the right order and morals (Northcote 2007: 2-3). The same tendency can be seen in Finnish discussions. 


\section{DISCOURSE AS A MEANING SYSTEM}

In what follows, I will present various discourses that create and maintain attitudes and opinions about the supernatural issues and about people with opposing views. The discourses have taken shape in historical processes, build on various presumptions, and each see the world from their own angle. Discursive formations have also been characterised as cultural models, interpretative repertoires, or meaning systems. They guide the way we see and understand the world and human activities in it. By giving only a limited set of roles or subject positions to people involved, discourses maintain stereotypes of people who do not think or act the same way as 'we' do. In social sciences, largely following Michel Foucault's views, one important task of discourse analysis has been to reveal the discursive nature of social and cultural 'facts' that people have taken for granted (Foucault 1991 [1972]: 50-53 et passim; Gee 1999: 7-8; Jokinen \& Juhila \& Suoninen 1993: 38-40; Pietikäinen \& Mäntynen 2009: 22-28; Potter \& Wetherell 1987). Here, the question is not about revealing some hidden prerequisites because there is an open dispute going on. Discussions about the supernatural concern the point where the legitimate assumptions have been violated. In such situations people can revise their assumptions about the world or deny or perhaps even stigmatise the deviant statements. A recurrent strategy when power and values are at issue is to associate deviant or opposing views with mental and moral flaws (e.g. Dijker \& Koomen 2007: 7; Northcote 2007: 3-5). My discourse analysis presents culturally shared views and opinions about the natural world, the supernatural, and the 'inappropriate' experiences. I study how people who have experienced something alien to the conventional meaning systems reinterpret and mould the hegemonic discourses to fit in. I also ask how they struggle against the negative labels embedded in them. Our social reality is shaped by competing views and an individual can rely on various discourses depending on the situation. Discourses can be overlapping, contradicting with, or supplementing each other. Some are marginal; others have become hegemonic (Jokinen \& Juhila \& Suoninen 1993: 17-19, 24, 29).

To define the various discourses in contemporary discussions about the supernatural, I have used three main criteria: 1) a discourse shares some basic assumptions about the world and what is right and reasonable in it; 2) a discourse uses certain vocabulary that reflects the values and assumptions embedded in it; and 3) discourses generally only provide a limited set of subject positions for people involved. Especially the third criterion is realised in my research material both as explicit judgments of the 'other' and as explicit denials of its validity especially by those to whom the role of the 'other' would be on offer. I will first present the discourses that approach the question as scientific and mental 
phenomena, and then discuss the discourses that involve spiritual themes and morals. Having already presented the mainstream attitudes dominating the public discussions, I focus on the attempts to make sense of the extraordinary experiences in a society that is generally unwelcoming to them.

\section{KEEPING IT SCIENTIFIC, MAKING IT MENTAL}

The discussions that involve both the experiencing minority and members of the non-experiencing majority roll around two major questions. The first is whether a spiritual world really exists or these experiences originate in the experiencing mind. The second is whether these experiences or phenomena are positive or negative. Not all discourses involve unequivocally either a positive or a negative stance. Furthermore, nearly similar arguments can actually advocate opposite views. For example, popular scientific reasoning has been used both to reject and to justify the existence of an invisible reality.

Science-oriented discourse follows the legitimate scientific worldview that is favoured in the public discussion and supported by central institutions such as education and health care. The basic assumption is that science defines and explains reality. 'Science-oriented' refers to the fact that real expertise is not required for participating in this discourse. The minimum requirements are the will to share a scientific worldview and the reliance on the legitimacy of scientific explanatory power and scientific vocabulary. The vocabulary of the popular scientific discourse borrows mostly from physics, biology, medicine, and psychology, including expressions such as natural laws, quantum theory, physical objects, electric impulses, and DNA. This dominant discourse expects modern Finns to be rational individuals who understand the natural laws and the material basis of existence. The other are portrayed as irrational, mistaken, blinded by some religious ideology, or perhaps mentally ill or stupid. Humorous expressions that support the popular scientific discourse are creative when they characterise the people who have deviant perceptions or beliefs. Thus, the vocabulary also includes expressions like nutcase, drunk, stupid, or magic mushrooms.

People who subscribe to a scientific worldview but still have experiences that oppose it are not necessarily willing to identify themselves with the irrational, hallucinating, or ridiculous other. Nor are they necessarily willing to reject the dominant discourse and build a marginal identity on the grounds of some spiritual subculture. Our informants frequently frame the reports of their experiences by declaring first that they are healthy, normal, and rational. The aspiration to see haunting as a natural phenomenon also tells us about the drive 
to belong to the rational and reasonable, who only accept natural phenomena. Thus, experiences that contradict the scientific worldview are frequently still interpreted within its frame. For example, a woman who wrote to researchers about experiencing spiritual beings and a time-space distortion as well as a strong feeling of a previous life, explained to them:

Myself, I reckon my own experiences are connected to physics, possibly to quantum physics, and the experience about a previous life I suppose to stem from the similarity of the DNAs of two people who lived in different times. I think that DNA includes memory. (MT 16/1 Ilona 12.3.2013)

To explain a discrepancy between the deviant phenomenon and contemporary science, it is typically noted that science will develop and explain things that today are not understood or accepted to be true or natural. Some of these statements share an optimistic tone, others are more critical of the present situation:

I really hope that research on human brain and cognition will develop. I do not find these so-called supernatural things otherworldly at all. Some day our time will be regarded as really primitive. I hope the time will come soon. (MT 16/2 Ilona 5.5.2013)

What today feels humbug can well be science in the future. Was it not the aim of science to develop and not to stick in its position and repeat the old-established attitudes? In ancient times, the highest truth claimed that the earth was flat. If someone stated otherwise he got killed. (US_YRI/ Stellaangela 23.2.2011, 21:02)

Naturally, most of the arguments that represent and strengthen this discourse deny the supernatural experiences and interpretations. They point to the lack of scientific proof and judge the supernatural or spiritual world as non-existent. For example:

Of course it would be nice to believe that life does not end in death, but yes it does. After death, we are only a lump of phosphorus, water, nitrogen, iron, etc. - a lifeless lump of atoms. (S24_KEF/tietopankki 1.8.2011, 21:21)

A widely accepted natural explanation is that supernatural experiences are produced by the human mind. However, the discussion about the imagining, hallucinating, and experiencing mind only partly belongs to the science-oriented discourse and therefore I present the mental discourse separately.

Mental discourse regards the experiences as real and seeks their origin in the characteristics and reactions of the human mind. These popular discussions and statements are informed by neurological and psychological research. 
Compared to the science-oriented discourse, the question is not primarily about ontology but about the bodily or chemical processes, as well as psychological tendencies that lead to these experiences. People engaged in this discourse discuss, for example, sleep paralysis, hypnagogic sensations, or out-of-body experiences, as well as the effects of medication, drugs, or compounds produced by the human organism itself. The next example is one of the numerous posts about sleep paralysis:

$H m m . .$. When I read these ghost stories it keeps coming to my mind that many of them could be experienced in a sleep paralysis. Namely, sleep paralyses could be interpreted as feelings like instant ghost attacks. In them one can get out of the body and start bouncing around the room thrown by an unknown figure, hear voices, see lights, and have no control upon anything, and feel as if totally awake but not able to move or shout. (Mix/JM 16.11.2007, 00:21)

If supernatural beliefs or experiences are judged negatively and seen as a problem, they can all be regarded as symptoms of a mental illness. Mental illnesses, of course, need to be taken seriously, and proper care to those who need it is important. But not all hallucinations are signs of an illness. Modern societies have been criticised for medicalising various behaviours, crises, and troubles in human life, along with health problems (Conrad \& Schneider 1992: 242-245; Koski 2016: 2-3). A central part of the criticism targets medicalisation as the professionals' strategy of assuming control (Barnet 2012). However, today medicalisation is not only an activity of professionals but is also realised as popular categorisations and labelling (Davis 2006: 54). Practically, participants in public discussion present their opinions in the form of stigmatising diagnoses. Comments in which medicalisation is used as stigmatisation, such as telling a person who reports having seen spirits to go and get therapy or medication, refer to mental discourse. However, such arguments lack interest in the actual mental processes. I rather see them as ways to repress discussion about the supernatural.

Without the stigmatising tendency, mental discourse is a legitimate interpretative frame for those who have experienced something themselves. It claims that the human mind is sensitive and reacts in various ways to stressful situations, such as grief.

When my child died in early spring, I grieved and cried so much that it cannot be described. He has appeared in my dreams twice... I know that these dreams have come to me as comfort, from my own subconsciousness. Longing makes a person believe in signs and omens, dreams come from 
one's own mind, they do not actually have anything to do with the deceased. (S24_HT/Kaipaava äiti 9.6.2010, 9:04)

Perhaps it is longing that makes us see what we wish. After my mother died, I often cried alone in the evenings. Then one morning I woke up and she was standing beside my bed, and I reached out my hand and said, 'How come you are here?' She looked at me, smiling, and disappeared. After that I had a tranquil feeling because it seemed that she had everything all right. (IS_Kumm/suopursu kukkii 16.2.2010, 22:53)

Mental discourse also allows flexibility between the normal qualities and malfunctions of the mind, or between positive and disturbing sensitivity. It can also be combined with spiritual explanations, such as the belief that certain mental abilities make some people more apt to contact the spiritual world than others. Likewise, it is compatible with New Age ideas about the mind as the source of divinity and cosmic connection (e.g. Hanegraaff 1996: 151, 204-207). An analytical approach to the topic can find the scientific explanations of the human mind as valid, yet insufficient. One of our informants explained the idea of conscious, collective dreaming, and referred to the mental discourse but argued there was also a supernatural component:

The question is not about sleep paralysis, dream, or otherwise a confused state of mind, but a fully conscious state, in which a person is aware of his / her environment through the so-called third eye. However, conscious dreaming and the experience of 'supernatural' through it require a lot of personal energy and practice, as well as a suitable set and setting. (MT 19/2 Henrik 2013)

He continues about his own experiences:

My personal experiences of the supernatural concern mainly the sensing of energy and a temporary improvement of sight. This is connected to the point that in a 'normal' state of consciousness, a very low amount of the potential of the human brain is used, compared to another state of consciousness, in which impulses and neurotransmitters flow in a totally different way in the brain. (MT 19/2 Henrik 2013)

The scientific approach and the reference to mental processes, as we have seen, do not only speak against the supernatural reality but are also harnessed to explain it. People who use scientific grounds to explain the supernatural frequently criticise the term itself, arguing that everything that happens in the world is actually natural. Some phenomena are just difficult to grasp and explain and are thus declared as supernatural. 


\section{DISCOURSES BASED ON THE EXISTENCE OF SPIRITUAL REALITY}

The conviction that a supernatural realm exists is shared both by Christianity and alternative spiritual believers. As sociologist Erich Goode puts it, conventional Christian beliefs are actually paranormal as well: they are contrary to the laws of nature (Goode 2000: 179). An important difference between paranormalism and Christianity is, however, that the latter is organised, controls religious ideas, and has a legitimate status in Western societies. A greater part of the experiences described in letters and internet discussions would not be accepted by Lutheran theology. The Lutheran Church allows for spiritual phenomena that are from God, but demands that those that are from Satan should be avoided and fought, and denies other possibilities, for example visits of the deceased. Practically, the religious experiences recognised in Lutheranism are feelings of relationship with the divine or experiences of the grace of God (Strohl 2005), or personal fulfilment and happiness (Zehnder 2010: 312). Christian education and discipline fighting heresy and superstition have a long history. Today, the Lutheran Church in the Nordic countries opposes the New Age and debates the syncretistic angel beliefs that have become popular (Gilhus 2012; Utriainen 2014: 250).

It has been suggested that Christian and paranormal beliefs would be mutually exclusive so that paranormal would be a substitute where Christian faith is weaker. However, according to numerous surveys this is not the case. The same people who believe in God and think that Satan is real are likely to have nonChristian paranormal beliefs as well (Goode 2000: 177-185; Mencken \& Bader $\&$ Stark 2008). The correlation is not the same for all Christians, though. Those who attend church at least once a week and associate with similar believers are likely to reject non-Christian paranormal beliefs and activities. These people are more committed to the dogma and are also controlled by their religious collective (Mencken \& Bader \& Stark 2008: 201-203; Orenstein 2002). These surveys have been conducted in the United States but the same pattern seems to prevail in our Finnish materials. There is difference between broad, popular interpretations and more fundamentalist ones.

Popular Christian discourse allows flexible ways to interpret Christianity and integrate various non-Christian spiritual experiences within the religious frame. Angels, the deceased, omens, and various meaningful signs can be interpreted by Christian terms. For example, a woman who has experienced a visit from her deceased mother, as well as several omens, explains: 
My experiences have made me sensitive to the distress of others and to sensing occasions and atmospheres. I find this state of affairs as positive and sometimes I feel that I could develop this sensitivity even further. $M y$ belief in God, the otherworld and angels is firm. I am only afraid to encounter something that involves real evil. (MT 61/2 Birgitta)

A man who has had several omens about deaths and an especially tragic premonition dream, writes:

I am a member of a Lutheran congregation. I am not an active member. I only go to church at Christmas and sometimes at Easter. I do not belong to any spiritual circles or such. But I try to explain my visions in terms of Christianity. In my opinion, there is no sense in belonging to a congregation and simultaneously seek answers in alternative spiritual literature or, on the other hand, to deny the spiritual side of events because it contradicts science. The dream that I told about was weird in a sense that it does not fit into my Christian worldview.... The dream has clearly strengthened my connection to the Christian world, despite the contradictions with Christian dogmas. (MT 30/2 Pauli)

Psychics say they have a contact with the souls of the departed. Myself, I do not think that way, but as a Christian I believe that visions are mediated by the Holy Spirit. I reckon that Christians are connected with each other in the Holy Spirit, just like leaves on different branches of a tree are connected to each other by the liquids flowing in the tree. (MT 30/1 Pauli)

Fundamental Christian discourse takes the experiences reported by others as real but does not allow flexible versions of the Christian dogma. To people who discuss their experiences, this discourse gives subject positions as misguided individuals who endanger the Christian world by associating with demonic powers. It condemns non-Christian spiritual phenomena and interprets the experiences as the activity of demons:

Probably the question is not about a deceased person but an evil spirit. Dead people cannot communicate any more. It is perhaps a demon who pretends to be a dead woman. By the way, it is intriguing that people are interested in supernatural issues, but once someone talks about Jesus and the God, they play the atheist card. (IS_VA/Rejjsk32 26.12.2014, 19:32)

Supernatural phenomena do exist. The Bible really tells us what 'ghosts' are and also how long they will astonish and even frighten people. The holy word of God reveals how these supernatural visions emerge and 
where they come from. Having abandoned his God and Creator, a formerly good angelic person became eager to occupy the position of his Creator and earn the worship of people. It was him that appeared as a snake to Eve and caused the loss of their home in Paradise as well as all evil to the world. (MT 52/x)

The latter writer had signed the text as Jehovah's Witness. My research material does not reveal the possible denomination of the writers if not explicated in the text. There are several Christian groups that share this stance towards supernatural phenomena. Here I find it sufficient to note that this stance is actively represented especially on internet sites that specialise in the supernatural or paranormal.

Alternative spiritual discourse is an open interpretative frame that adopts influences from various sources and, accordingly, uses their vocabularies such as astral bodies, energies, chakras, and the third eye. People who are interested in alternatives to the mainstream material worldview or experience things that do not fit into it, develop new outlooks with the help of literature, as well as courses and meetings organised by societies in this field. Some people use freely the reserve that we could well label as occulture. Others are involved in one particular ideology. In Finland, spiritualism and theosophy have a long tradition, and recently a wide array of New Age and occult movements have entered the scene. Finnish records show that in 2011 there were 34 esoteric societies, 93 that presented New Age spirituality, and 20 that could not be categorised as any particular tradition (Palmu et al. 2012: 32). In my research material, spiritual explanations are usually applied to questions of death and afterlife:

Soul-spiritually, when a human being dies, he/she is followed as a spiritual being by a so-called ethereal body, which, for a moment, enables feelings of a parallel world, such as touches, ghostlike visions, etc. (MT 18/2 Esko)

People who feel that they have gained a wider and deeper knowledge may regard it as a gift and ability to see truths to which the majority is blind. Some writers tell about being in contact with wider universal spheres and energies that would not be graspable to everyone, at least not yet, as the majority is reluctant.

Human understanding is limited. What is not grasped is willingly invalidated one way or another. Simply because human comprehension is insufficient to handle everything, especially issues about which there is no prior information or which have no stable credibility created by some authority. This is a typical human relation to things. It is human and understandable. (MT 7/Hannele 17.6.2013) 
While the majority of people with supernatural or paranormal experiences keep quiet about them, it has been estimated on grounds of various surveys that there is a strong occult undertone in contemporary culture and that it correlates with the rapid development of science and technology (Ervasti 2006: 266).

\section{A QUEST FOR LEGITIMACY, AUTHORITY, AND VALUES}

People with supernatural beliefs or experiences suffer from the marginality of their worldview and the mocking and stigma that are activated whenever these issues are publicly discussed. This situation has been changing for some time now. In 2011, two discussants in the Paranormal blog noted:

I think that luckily the atmosphere is developing in a more positive direction all the time. The more mainstream these issues have become, the more people dare speak about them. Today, people with experience of UFOs and stuff seem to share more openly in media, too. (PaSS/Wespa 14.6.2011, 23:56)

Yes, you are right. I believe that more and more of us are 'awakened'. People are also encouraged to speak about things, at least via the Internet. People did not have a chance of this type of communication before. (PaSS/ Ogeli 15.6.2011, 00:27)

Surveys in various Western countries have suggested that people with lower income and less education would be more likely to have supernatural beliefs. In addition, women are more likely to hold supernatural beliefs than men. Support to this so-called marginalisation theory has recently diminished. It seems that attitudes towards science and technology are more decisive in this respect: supernatural beliefs go together with a negative attitude toward science (Ervasti 2006: 264; Mencken \& Bader \& Stark 2008: 195-200). As the impact of education was notable only on the academic level, the controversy between science and the supernatural is not necessarily a question of education and ignorance but rather of values. Highly educated people are more committed to scientific thinking. In Finnish surveys, people who identified themselves as religious or spiritual were more likely than others to agree with the claims "we trust in science too much instead of belief", and "our lifestyle changes too rapidly because of science and technology" (Ketola \& Kääriäinen \& Niemelä 2007). It has been noted that New Age spirituality is critical to information mediated by others, as well as to scientific objectivity. Personal experiences are regarded as the most reliable source of truth (Partridge 2005: 75-76). Also 
in my research material, dialogue with the sciences has been experienced as belittling and one-sided.

Personally, I have encountered dozens of experiences concerning the otherworld, but it is impossible to prove them afterwards. How to prove that a prayer makes a person wake up from a coma, without having several eyewitnesses, etc... On the other hand, spiritual events that are alien to science are usually easy to explain as coincidences, events inside one's mind, or caused by medication. (MT 30/2 Pauli)

Adherents to the alternative views scold scientists for their fear and prejudices that prevent a proper research on these issues. One commentator criticises the restricted scope of scientific methods:

Imagine that you have a bathtub full of water, which you scoop with a spaghetti sieve. A 'scientific' experiment shows that there is no water in the tub because no water was left in the sieve. (IS_Vir/Palikkatiedettä palikkapäille 23.1.2014, 03:04)

While the contemporary spiritual movements are critical towards science, ordinary people who all of a sudden encounter something beyond reality prefer to stick to the legitimate scientific explanations. The institutionalised sources of worldviews - Christianity and natural sciences - can be slightly stretched so that the experience can fit in a legitimate interpretative frame. The shift from supernatural to scientific interpretations can be seen in the fact that even the experiencing individuals themselves often think that the source of the encounter was in their own mind.

To sum up, there is an ongoing lively discussion about the supernatural and paranormal on the Internet. The emergence of these topics in the mainstream media has triggered both positive and negative reactions. The supernatural is likely to be acceptable if it conforms to some well known belief system or if it is handled as fiction or entertainment. Random experiences are easily labelled as hallucinations. Even though the atmosphere has become more open towards extraordinary phenomena, it is common that the experients and believers report mocking and stigmatisation. The contemporary debate mainly focuses on the relationship between the supernatural and science. It not only concerns ontological questions but also disputes about the legitimate methods of studying reality. Furthermore, the flaws of the opposite party are saliently brought up. The proponents of the supernatural are portrayed as gullible, mentally unstable, and ignorant. The sceptics, in turn, are accused of being prejudiced, scared of new ideas and defending mainly their ideology and not the truth. In addition to the debate between these established parties there are people 
who struggle with their own worldview and identity, unwilling to reject the mainstream worldview and to adopt a marginal identity. The mental discourse that can actually combine with both scientific and supernatural interpretations would seem to be the most plausible frame for an understanding between the disputing parties. However, concord does not seem likely as long as the dispute concerns not only knowledge about these issues but also values and identities.

\section{NOTES}

1 This research was undertaken as part of the Mind and the Other project funded by the Academy of Finland within the research programme The Human Mind, No. 266573.

2 Folklore scholars used to distinguish memorates as experience narratives showing personal commitment to the experience from legends that adopt various forms to convey the traditional core (Pentikäinen 1968; von Sydow 1948: 86-88). Since tradition and the alleged 'true' experiences often intermingle in narrative performance, some scholars have found the division impractical and the memorate has later been given a stylistic meaning only. Furthermore, the meaning of the memorate has been reduced into the rendition of the legend in first person (Dégh 2001: 40-42, 58-63). Thus, the term memorate is no more apt to make unequivocally the difference it was designed to make. Still, there are contexts in which the personal commitment (which used to be the point of second- and third-hand memorates compared to legends) is distinctive of the narrative.

3 From a linguistic point of view, this verbal action that I here call public discussion could also have been called public discourse as a collectively constructed communicative sphere (see Gee 1999). I chose the word discussion to avoid confusion between discourses as meaning systems and this larger formation that is characterised by its status and legitimacy, as well as the publicity of the forums. In sociology, public sphere (e.g. Keane 1995) resembles this but perhaps without the emphasis on vernacular participation, which is my point of view as a folklorist.

4 While newspapers represent objectivity, various weekly journals appreciate touching life stories and polemic discussion about hot topics. A Finnish periodical which, among other topics, handles experiences of angels or mystical issues, is characterised in an advertisement as a trusted friend that offers great experiences and people to identify with, and has a good story as its core (see http://www.lehtimesta.fi/product/28/seuralehti-maaraaikainen-tilaus, last accessed on April 20, 2016).

5 For example, Saska Saarikoski, a journalist working for Helsingin Sanomat, the leading newspaper in Finland, deserved public critique from colleagues after writing reportage about his visit to specialists of the supernatural (e.g. Raevaara 2014).

\section{ARCHIVAL MATERIALS}

MT: Letters sent to the research project "Mind and the Other". Archives of the School of History, Culture and Arts, University of Turku. 


\section{REFERENCES}

Barnet, Robert J. 2012. Medicalization of Life. Canadian Dimension, Vol. 46, No.4, pp. 50-52.

Casanova, José 2012. Are We Still Secular? Explorations on the Secular and the PostSecular. In: Peter Nynäs \& Mika Lassander \& Terhi Utriainen (eds.) Post-Secular Society. New Brunswick, NJ \& London: Transaction Publishers, pp. 27-46.

Conrad, Peter \& Schneider, Joseph W. 1992. Deviance and Medicalization: From Badness to Sickness. Expanded edition, with a new afterword by the authors. Philadelphia: Temple University Press.

Davis, Joseph E. 2006. How Medicalization Lost Its Way. Social Science and Modern Society, Vol. 43, No. 6, pp. 51-56. http://dx.doi.org/10.1007/BF02698486.

Dégh, Linda 2001. Legend and Belief: Dialectics of a Folklore Genre. Bloomington \& Indianapolis: Indiana University Press.

Dijker, Anton J. M. \& Koomen, Willem 2007. Stigmatization, Tolerance and Repair: An Integrative Psychological Analysis of Responses to Deviance. Cambridge: Cambridge University Press. Available at http://www.cambridge.org/us/academic/ subjects/psychology/social-psychology/stigmatization-tolerance-and-repairintegrative-psychological-analysis-responses-deviance\#contentsTabAnchor, last accessed on April 21, 2016.

Ervasti, Heikki 2006. Suomalaisten yliluonnolliset uskomukset. [Paranormal Beliefs in Finland.] Yhteiskuntapolitiikka, Vol. 71, No. 3, pp. 259-269. Available at https:// www.julkari.fi/bitstream/handle/10024/100142/063ervasti.pdf?sequence=1, last accessed on June 14, 2016.

Ev.lut.kirkko 2014 = Suomen evankelis-luterilainen kirkko. Jäsenet. [Evangelical Lutheran Church of Finland. Membership.] Available at http://evl.fi/EVLfi.ns f/0/68ED832793E78AF5C22575EF003AD029?OpenDocument\&lang=FI, last accessed on April 21, 2016.

Foucault, Michel 1991 [1972]. The Archaeology of Knowledge. London \& New York: Routledge.

Gee, James P. 1999. Introduction to Discourse Analysis: Theory and Method. London \& New York: Routledge.

Gilhus, Ingvild Sælid 2012. Angels in Norway: Religious Border-Crossers and BorderMarkers. In: Marion Bowman \& Ülo Valk (eds.) Vernacular Religion in Everyday Life: Expressions of Belief. Sheffield: Equinox, pp. 230-245.

Goode, Erich 2000. Paranormal Beliefs: A Sociological Introduction. Prospect Heights: Waveland Press.

Hanegraaff, Wouter J. 1996. New Age Religion and Western Culture: Esotericism in the Mirror of Secular Thought. Leiden: Brill.

Heelas, Paul \& Woodhead, Linda 2005. The Spiritual Revolution: Why Religion Is Giving Way to Spirituality. Oxford: Blackwell.

Hiiemäe, Reet forthcoming. "What Is This Mystical Bogeyman or Ghost Called?” Sharing Nightmare Experiences on Internet Forums. Bulgarian Folklore: Journal of Folkloristics, Ethnology and Anthropology.

Hill, Annette 2011. Paranormal Media: Audiences, Spirits and Magic in Popular Culture. Abingdon \& New York: Routledge. 
Jokinen, Arja \& Juhila, Kirsi \& Suoninen, Eero 1993. Diskurssianalyysin aakkoset. [Basics of Discourse Analysis.] Tampere: Vastapaino.

Keane, John 1995. Structural Transformations of the Public Sphere. The Communication Review, Vol. 1, No. 1, pp. 1-22. http://dx.doi.org/10.1080/10714429509388247.

Ketola, Kimmo 2007. Spiritual Revolution in Finland? Evidence from Surveys and the Rates of Emergence of New Religious and Spiritual Organizations. Nordic Journal of Religion and Society, Vol. 20, No. 1, pp. 29-39.

Ketola, Kimmo \& Kääriäinen, Kimmo \& Niemelä, Kati 2007. Näkyykö usko elämässä? Uskonnollisuuden vaikutus suomalaisten asenteisiin, arvomaailmaan ja moraalikäsityksiin. [Does Belief Show in Life? The Impact of Religiosity in Opinions, Values, and Ethics of Finns.] In: Sami Borg \& Kimmo Ketola \& Kimmo Kääriäinen \& Kati Niemelä \& Pertti Suhonen (eds.) Uskonto, arvot ja instituutiot: Suomalaiset World Values-tutkimuksissa 1981-2005. [Religion, Values, and Institutions: The Finns in World Values Research in 1981-2005.] Yhteiskuntatieteellisen tietoarkiston julkaisuja 4. Tampere: Yhteiskuntatieteellinen tietoarkisto (FSD), pp. 60-85. Available at http://www.fsd.uta.fi/fi/julkaisut/julkaisusarja/FSDjs04_ uskonto.pdf, last accessed on April 21, 2016.

Koski, Kaarina 2016. Yliluonnollista vai patologista? Kummien kokemusten muuttuvat tulkinnat. [Supernatural or Pathological? Changing Interpretations of Uncanny Experiences.] Elore, Vol. 23, No. 1, pp. 1-22. Available at: http://www.elore.fi/ arkisto/1_16/koski.pdf, last accessed on June 10, 2016.

Laiho, Suvi \& Kaunonen, Marja \& Aho, Anna Liisa 2014. Yliluonnolliset ilmiöt lapsen kuoleman jälkeen. [Supernatural Phenomena after Child's Death.] Thanatos, Vol. 3, No. 2, pp. 45-60. Available at https://thanatosjournal.files.wordpress. com/2014/11/laiho_yliluonnolliset.pdf, last accessed on June 10, 2016.

Lassander, Mika 2014. Post-Materialist Religion: Pagan Identities and Value Change in Modern Europe. London: Bloomsbury.

Mencken, Carson F. \& Bader, Christopher D. \& Stark, Rodney 2008. Conventional Christian Beliefs and Experimentation with the Paranormal. Review of Religious Research, Vol. 50, No. 2, pp. 194-205. Available at https://www.jstor.org/stable/ i20447554, last accessed on April 21, 2016.

Northcote, Jeremy 2007. The Paranormal and the Politics of Truth: A Sociological Account. Exeter: Imprint Academic.

Orenstein, Alan 2002. Religion and Paranormal Belief. Journal for the Scientific Study of Religion, Vol. 41, No. 2, pp. 301-311. http://dx.doi.org/10.1111/1468-5906.00118.

Palmu, Harri \& Salomäki, Hanna \& Ketola, Kimmo \& Niemelä, Kati 2012. Haastettu kirkko. Suomen evankelis-luterilainen kirkko vuosina 2008-2011. [The Challenged Church: The Evangelical Lutheran Church of Finland in 2008-2011.] Kirkon tutkimuskeskuksen julkaisuja 115. Tampere: Kirkon tutkimuskeskus. Available at http://sakasti.evl.fi/sakasti.nsf/0/4D9073DDB9C38745C22576F20030A70E/\$ FILE/Haastettu\%20kirkko.pdf, last accessed on April 21, 2016.

Partridge, Christopher 2005. The Re-Enchantment of the West: Volume 1: Alternative Spiritualities, Sacralization, Popular Culture and Occulture. London \& New York: Bloomsbury T\&T Clark. 
Partridge, Christopher 2013. Occulture is Ordinary. In: Egil Asprem \& Kennet Granholm (eds.) Contemporary Esotericism. Sheffield \& Bristol: Equinox, pp. 113-133.

Pechey, Rachel \& Halligan, Peter 2012. Prevalence and Correlates of Anomalous Experiences in a Large Non-Clinical Sample. Psychology and Psychotherapy: Theory, Research \& Practice, Vol. 85, No. 2, pp. 150-162. http://dx.doi.org/10.1111/ j.2044-8341.2011.02024.x.

Pentikäinen, Juha 1968. Grenzprobleme zwischen Memorat und Sage. Temenos: Nordic Journal of Comparative Religion, Vol. 3, pp. 136-167.

Pietikäinen, Sari \& Mäntynen, Anne 2009. Kurssi kohti diskurssia. [A Course towards Discourse.] Tampere: Vastapaino.

Potter, Jonathan \& Wetherell, Margaret 1987. Discourse and Social Psychology: Beyond Attitudes and Behaviour. London: Sage.

Raevaara, Tiina 2014. Tarinoita tieteestä: Kuukausiliite hurahti huuhaa-kaksosiin. [Stories about Science: Kuukausiliite Went Crazy about Humbug-Twins.] Suomen Kuvalehti, March 1. Available at http://suomenkuvalehti.fi/tarinoitatieteesta/ kuukausiliite-hurahti-huuhaa-kaksosiin/, last accessed on April 22, 2016.

Schechter, Harold 2001 [1988]. The Bosom Serpent: Folklore and Popular Art. New York: Peter Lang.

Skultans, Vieda 1997. Theorizing Latvian Lives: The Quest for Identity. The Journal of the Royal Anthropological Institute, Vol. 3, No. 4, pp. 761-780. DOI: $10.2307 / 3034038$.

Strohl, Jane E. 2005. James and Luther on the Heart of the Reformation Faith. Dialog: A Journal of Theology, Vol. 44, No. 1, pp. 17-18. http://dx.doi.org/10.1111/j.00122033.2005.00234.x.

Sydow, Carl Wilhelm von 1948. Kategorien der Prosa-Volksdichtung. In: Laurits Bødker (ed.) C. W. V. Sydow: Selected Papers on Folklore Published on the Occasion of His 70th Birthday. Copenhagen: Rosenkilde and Bagger, pp. 60-85.

Utriainen, Terhi 2014. Angels, Agency, and Emotions: Global Religion for Women in Finland? In: Terhi Utriainen \& Päivi Salmesvuori (eds.) Finnish Women Making Religion: Between Ancestors and Angels. New York, NY: Palgrave Macmillan, pp. 237-254. Available at http://www.palgrave.com/la/book/9781137388681, last accessed on June 14, 2016.

Woodard, Fredrick James 2012. A Phenomenological Study of Spontaneous Spiritual and Paranormal Experiences in a 21st Century Sample of Normal People. Psychological Reports, Vol. 110, No. 1, pp. 73-132.

Zehnder, David J. 2010. The Hermeneutical Keys to William James's Philosophy of Religion: Protestant Impulses, Vital Belief. Forum Philsophicum: International Journal for Philosophy, Vol. 15, No. 2, pp. 301-316. Available at http:// web.b.ebscohost.com/ehost/pdfviewer/pdfviewer?sid=1fa1f36b-b2c0-4deb-95147107d8ae4521\%40sessionmgr114\&vid=0\&hid=102\&preview=false, last accessed on April 22, 2016. 


\section{INTERNET SITES}

IS_Kumm: Call for ghost stories in IS news on the Internet, 16.2.2010, Kerro kummitustarina! [Tell a ghost story!] Internet page no longer available. The content is in possession of the author.

IS_VA: Internet comments to a video clip on a daily newspaper's internet page, 26.12.2014, Vailla selitystä: Pelästyttikö petetty nainen asiakkaita Imatran Valtionhotellissa? [Without explanation: Did a cheated woman scare customers in the state hotel of Imatra?] Available at http://www.iltasanomat.fi/viihde/art-1419565508416.html, last accessed on April 22, 2016.

IS_Vir: Internet comments to IS news, 22.1.2014, Suomalaistohtorit näkevätyliluonnollisia asioita - tontut ja haltiat arkipäivää. [Finnish doctors see supernatural things Gnomes and spirits are everyday reality.] Available at http://www.iltasanomat. fi/kotimaa/art-1288645125959.html, last accessed on April 22, 2016.

Mix: A straw poll thread on a music-related Internet community's discussion site, topic started on 15.11.2007. Aaveet uskotko niihin? [Ghosts - Do you believe in them?] Available at http://www.mikseri.net/clubs/thread.php?topic_id=30188, last accessed on April 22, 2016.

MNYks: Internet comments of women's magazine MeNaiset, 17.1.2015. Pariskunta hoitaa sairauksia yksisarvishoidoilla - uskaltautuisitko kokeilemaan? [A couple heals illnesses by unicorn healing - Would you dare to try?] Available at http:// www.menaiset.fi/node/29470 accessed 9.9.2015, last accessed on April 22, 2016.

PaSS:InternetForum Paranormaaliblogi, discussion Suvaitsematon Suomi. [IntolerantFinland.] Available at http://paranormaaliblogi.net/index.php/2011/06/14/suvaitsematon-suomiparanormaaleja-kokeneita-syrjitaan-is-keskustelut/\#comments, last accessed on April 22, 2016.

S24_HT: Internet Forum Suomi24, discussion 'Henkimaailma' totta! ['Spiritual world' is true!] Available at http://keskustelu.suomi24.fi/t/4211042\#, last accessed on April 22, 2016.

S24_KEF: Internet Forum Suomi24, discussion Kuolemanjälkeinen elämä on fakta. [Life after death is a fact.] Available at http://keskustelu.suomi24.fi/t/2619256\#, last accessed on April 22, 2016.

US_YRI: Internet comments of Uusi Suomi newspaper, 18.2. 2011. Väite: Yliluonnollisille ruumiista irtautumiselle selitys. [Argument: Supernatural out-of-body experiences explained.] Available at http://www.uusisuomi.fi/ymparisto/109450-vaiteyliluonnollisille-ruumiista-irtautumisille-selitys\#comments, last accessed on April 22, 2016.

Yleisradio 2015: Julkisen sanan neuvoston langettava päätös. [Conviction by the Council of Mass Media.] YleX 21.5. Available at http://yle.fi/ylex/uutiset/julkisen_sanan_ neuvoston_langettava_paatos/3-8007463, last accessed on April 22, 2016.

YleX: Internet article and comments in YleX news site 26.1.2015: Alle tonnilla Yksisarvishoitajaksi. [Become a unicorn healer by less than a thousand euros.] Available at http://yle.fi/ylex/uutiset/alle_tonnilla_yksisarvishoitajaksi/3-7762128, last accessed on June 9, 2016. 